Ivan BODROŽIĆ

Katolički bogoslovni fakultet u Splitu ivan.bodrozic@gmail.com
UDK 272-563.5]:27-789.2

Izvorni znanstveni članak

Primljen: 16. lipnja 2020.

Prihvaćen: 20. listopada 2020.

\title{
PROCES NASTANKA LITURGIJE ČASOVA I KRŠĆANSKO POIMANJE VREMENA U KONTEKSTU BENEDIKTINSKE DUHOVNOSTI I PRAVILA
}

\begin{abstract}
Autor u ovom članku propituje proces nastanka liturgije časova, službene molitve Crkve koja je bila osmišljena kao molitva kojom se posvećuje vrijeme. Nakon što je definirao terminološki okvir pojmova »liturgija časova« i »vrijeme«, autor započinje istraživanje vraćajući se u razdoblje apostolske zajednice u kojemu će, iščitavajući novozavjetne tekstove, zaključiti da je molitva trebala sadržavati tri bitna obilježja: biti neprekidna, zajednička i biblijska. U postapostolskom razdoblju, prateći ovu nit, pokazat će kako se je u kršćanskim zajednicama nametnula molitva psalama kao povlaštena kršćanska molitva (naravno uz Gospodnju molitvu) koja je odgovarala tim kriterijima. Tako iznosi na vidjelo da su kršćani već u 2. i 3. stoljeću razvili molitvu u pet molitvenih trenutaka tijekom dana: Jutarnja i Večernja su bile stožerne molitve, a k njima su se još pridodavale molitve Trećega, Šestoga i Devetoga časa. Po svemu sudeći, u naznačeno vrijeme molili su se pojedini psalmi, no danas se ne može točno zaključiti koji. Iz ovoga rada postaje razvidno da važan doprinos cijelom procesu nastanka liturgije časova daje monaški pokret, pri čemu će najvažniju ulogu za zapadno kršćanstvo odigrati sveti Benedikt koji će svojim Pravilom utisnuti poseban pečat kršćanskoj duhovnosti. Odgovarajući na izazove vremena, on će molitvi monaha dati ciklički oblik, te će ritam od pet molitvenih trenutaka u danu podići na sedam, to jest osam ako se uključi i noćno Bdjenje. Polazeći od činjenice da broj sedam označava savršenstvo, ritam od sedam dnevnih molitvenih točki simbolički će označavati molitvu kao neprekinutu aktivnost. A s obzirom na tjedni molitveni ciklus, Benedikt će odrediti da se unutar njega izmoli svih 150 psalama Psaltira, čime će biti osigurana cjelovitost molitve. Prema njegovu Pravilu molitva psalama, ili »Djelo Božje« kako ga on zove, nije samo ritmizirala monahov cijeli dan i tjedan, već ga je ucjepljivala u povijest spasenja pretvarajući njegovo vrijeme u blaženu vječnost. Kao sredstvo posvete vremena koje ima svoj neprekinuti tijek u dnevnim i tjednim ciklusima, molitva časova je do kraja odgovarala evanđeoskim kriterijima koje je zadao Isus i apostolska zajednica, te je razumljivo zašto je sve do danas prihvaćena u Crkvi kao službena molitva.
\end{abstract}

Ključne riječi: Liturgija časova, vrijeme, Pravilo sv. Benedikta, benediktinska duhovnost, molitva, Psaltir 


\section{UVOD}

Tema zadana naslovom vrlo je složena i zahtjevna, jer joj je cilj propitati proces koji se događao u vremenskome rasponu od otprilike pet stoljeća, koliko je trebalo da se od molitava apostolske zajednice razvije sustavna i organička molitva Crkve nazvana molitvom časova, to jest liturgijom časova. Kako ova molitva nije nastala odjednom, već u konkretnom povijesnom procesu koji je na Zapadu došao svome vrhuncu zahvaljujući benediktinskim monasima, temeljna je nakana ovoga rada rekonstruirati put koji je Crkva prošla u hodu od apostolskih vremena do svetoga Benedikta tražeći najprikladniji način slavljenja Boga molitvom. Moguće je rekonstruirati spomenuti put slijedeći teološka svjedočanstva koja su ostala kao pokazatelj određenih dionica, lakših ili težih, pa onda i napora koje su učinili ljudi Crkve koji su sudjelovali $\mathrm{u}$ tom procesu. Ako i nije uvijek izvedivo iz tekstova koje posjedujemo istražiti cjelovito ili dokumentirati iscrpno proces koji se dogodio, rekonstrukcija je ipak olakšana time što imamo veliku jasnoću s obzirom na polazišnu i na odredišnu točku ovog puta. Polazište je život Isusa Krista i njegov nauk o molitvi, a cilj do kojega je Crkva došla, razvijajući molitvu sukladno načelima definiranim u početku Pravilo je sv. Benedikta. Sveti Benedikt je, naime, u svome monaškom Pravilu ostavio iscrpne upute s obzirom na zajedničku molitvu u samostanu, što će Crkva na Zapadu preuzeti i ozakoniti kao kanonsku molitvu obvezatnu za službenike Crkve i redovnički stalež, a toplo preporučiti i svim drugim vjernicima. Stoga će raspored istraživanja pretpostaviti da se najprije definira pojam liturgije časova, te da se potom objasni kršćansko poimanje vremena s kojim je ova molitva usko vezana jer je bila strogo raspoređena na određene časove dana. Nakon toga će se poći u teološko-povijesnu rekonstrukciju procesa nastanka liturgije časova od apostolskih vremena do vremena sv. Benedikta.

\section{2. ŠTO JE LITURGIJA ČASOVA?}

Prvi korak ovoga istraživanja je utvrditi značenja pojma liturgija časova koji je bitni sastavni element i središnji sadržaj proučavanoga predmeta. Nakana je u ovom koraku utvrditi točan sadržaj i okvire unutar kojih se kreće povijesno-teološko istraživanje s obzirom na značenje riječi liturgija časova. Liturgija časova jedna je od najvažnijih kršćanskih molitava koju su tijekom stoljeća prakticirali i prakticiraju monasi i klerici, kao i druge posvećene oso- 
be. ${ }^{1}$ U životu Crkve kao zajednice vjernika liturgija časova zauzima povlašteno mjesto molitve, jer se ne radi o proizvoljnoj molitvi pojedinca ili skupine vjernika, kao ni o pučkoj ili privatnoj pobožnosti. Liturgija časova je molitva Crkve kao zajednice Kristovih vjernika koja stječe obilježje službene molitve prakticirane u Crkvi i ponuđene vjernicima kao obrazac ispravnog načina moljenja, po čemu onda i nosi naziv ne samo molitve, već i liturgije. A liturgija je bogoštovni čin Crkve, ili bolje: bogoštovni čin samoga Krista koji, po njegovu daru, postaje bogoštovljem Crkve, to jest liturgijom Crkve. ${ }^{2}$ Stoga se za molitvu časoslova kaže da nije samo molitva Crkve, već je »sveta služba, sveti čin proslave Boga i odjelotvorenja ljudskoga spasenja. Po liturgiji Crkve Krist 'izvršuje djelo ljudskoga otkupljenja i savršene proslave Boga' (SC 2008: 5), i to ne samo kad se u Crkvi slave euharistija i drugi sakramenti, nego i kad se vrši liturgija časova. U tom obliku liturgijske molitve nazočan je sam Krist: u okupljanju zajednice, u naviještanju Božje riječi, u molitvi i psaliranju zajednice (SC 2008: 7). Zato se liturgija Crkve izdiže iznad 'molitve' ili prošnje okupljenih vjernika: po njoj se izvršuje i posvećenje čovjeka i slavljenje Boga. Zbog takve sakramentalne naravi liturgiji časova, poslije slavlja sakramenata, pripada najčasnije mjesto. Štoviše, tu molitvu-liturgiju Crkva priznaje svojom molitvom.« (CRNČEVIĆ; ŠAŠKO 2009: 525). Autori također podsjećaju da je drevna monaška tradicija ovaj oblik molitve nazivala jednostavno opus Dei, tj. »Djelo Božje«.

Po svojoj strukturi liturgija časova satkana je od psalama, ${ }^{3}$ crkvenih himana i molitava te je bitno vezana s pojmom vremena jer je raspoređena $u$ određena doba dana, jednako kao što je i artikulirana u četiri tjedna. ${ }^{4}$ Molitva $\mathrm{u}$ vremenu ili slavljenje Boga u vremenu ukazuje na bitan smisao ove molitve i daje naslutiti njezinu cikličku strukturu koja prati ljudski život. Doista, neophodno je naglasiti da je »liturgiji časova svrha posvetiti dan i cjelokupno čovjekovo djelovanje«, kako stoji u Općoj uredbi liturgije časova br. 11 ( $\check{C} a-$ soslov rimskoga obreda I: 18). Odatle proizlazi da je nezaobilazni čimbenik

1 Ovaj se rad prvenstveno bavi razvojem liturgije časova na Zapadu, to jest u latinskoj ili zapadnoj Crkvi koja će preuzeti i promicati način molitve koju je sv. Benedikt definirao u svom Pravilu.

2 Više o tome vidi u MARSILLI 1988: 678-680.

3 O važnosti psalama i Psaltira kao kršćanske molitve vidi više u PEHAR 2020: 2-6.

4 Vidjet ćemo da je prema Pravilu sv. Benedikta bila raspoređena u tjedan dana, no cilj ovoga rada nije istraživati razlike između nekadašnjega i današnjega načina molitve časoslova, pa ćemo izostaviti pitanja koja se tiču reformi brevijara koje su nastajale u nekim kasnijim povijesnim trenucima. 
liturgije časova njezina povezanost s poimanjem vremena kao takvoga, te sa strukturom dana podijeljenoga u sate. Jer je zamišljena i osmišljena kao molitva koja posvećuje ljudsko vrijeme, bitno je određena i strukturirana vremenom, koje je njezin ključni sadržajni i interpretativni element (CRNČEVIĆ 2009: 526-527).

\section{KOJIM SE VREMENOM SLUŽI LITURGIJA CRKVE?}

Upravo zbog važnosti koju vrijeme ima za liturgiju časova, neizostavno je postaviti pitanje kojim se vremenom služi liturgija Crkve, ma kako to pitanje moglo izgledati čudno. Premda je, s jedne strane, vrijeme kategorija koja na istovjetan način vrijedi za sve ljude bez iznimke, ipak, s druge strane, nisu svi ljudi imali istu predodžbu vremena niti su ga tumačili na istovjetan način. Znamenita je aporija sv. Augustina iz Ispovijesti (XI,14,17) o shvaćanju vremena. Vrijeme je, prema njemu, svojevrsna zagonetka između onoga što je bilo, što jest i što će doći, te kad se izgovori riječ vrijeme, svi znaju o čemu je riječ, međutim malo tko ga može dobro definirati. ${ }^{5}$ Problem pred kojim se našao sveti Augustin, problem je kasnoantičkoga čovjeka koji se tražio u vremenu i pred vremenom nastojeći se izboriti za svoje mjesto. »Što je vrijeme?« - odgovor su na razini teorije pokušavali dati helenistički filozofi, no na razini praktičnoga života nitko nije mogao zaustaviti njegovo protjecanje niti se istrgnuti iz njegova moćnog zagrljaja. No, onkraj filozofije u kasnoantičkom društvu svoj odgovor na pitanje i problem vremena nastojali su artikulirati i kršćani, uvjereni da sam Bog dolazi ususret čovjeku kako bi mu pomogao pobijediti kotač prolaznosti i orijentirati se u nestalnosti vremena koje potpuno izmiče ljudskoj moći. Upravo zato, jer se i sveti Benedikt kao čovjek svoga vremena našao pred izborom koji koncept vremena usvojiti i primijeniti u molitvi, neophodno je analizirati kako helenistički tako i kršćanski sustav vremena i pogled na vrijeme u kasnoj antici, što će omogućiti da se dođe do pouzdanih zaključaka o njegovom specifičnom doprinosu rješavanju poteškoće koju je ljudima nametnulo vrijeme.

5 »Što je dakle vrijeme? Ako me nitko ne pita, znam, ali ako bih htio nekome na pitanje to razjasniti, ne znam; ipak sa sigurnošću mogu reći da znam, kad ne bi ništa prolazilo, da ne bi bilo prošloga vremena, i kad ne bi ništa dolazilo, da ne bi bilo budućega vremena, i kad ne bi ništa postojalo, da ne bi bilo sadašnjega vremena« (AUGUSTIN 1973: 263). 


\subsection{Helenističko poimanje vremena}

Što se tiče helenističkoga poimanja vremena, stari su Grci poznavali dva

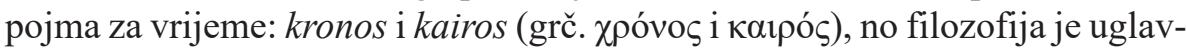
nom koristila samo jedan, i to kronos - vrijeme shvaćeno kao gibanje i podložno filozofskom promatranju (REALE 1997: 273). ${ }^{6}$ Kairos je kao prikladno vrijeme ili sretan trenutak ostao izvan filozofskoga promatranja. U svom istraživanju Marija Pehar je pokazala u kakvom su odnosu bili kronos i kairos $\mathrm{u}$ antičkom svijetu: »Kronos je vrijeme određeno gibanjima Sunca i zvijezda i Zemljina odnosa prema njima, proces mjerljiv kronometrom, vrijeme koje trajno prolazi, neumitno teče, kao takvo ono je za čovjeka ugroza, jer u konačnici vodi smrti. Nasuprot tomu, kairos označava jedinstveni i odlučujući trenutak unutar ove vremenitosti, osobito povoljnu priliku, neke vrste imaginarno vrijeme. Može se reći da su kronos i kairos u napetom međuodnosu. Dok je kronos kvantitativne naravi, kairos je pojam kvalitativne naravi« (PEHAR 2014: 52-53). ${ }^{7}$ Osim toga, valja također istaknuti da je grčki kronos bio uvijek jači od kairosa, te je pobjeđivao taj eventualni sretni trenutak za koji je jamčio bog Kairos, toliko brz i neuhvatljiv, ali i opasan i oštar poput britve. Grčki kronos je pokazivao nadmoć, jer je kairos bio ono nestalno sada, nestalni trenutak prolazne sreće koju u svakom slučaju ljudi nisu mogli zadržati dalje od smrti, te tako nije bilo u ljudskoj moći zaustaviti ga i njime ovladati.

Vrijeme, dakle, bilo da je shvaćeno kao gibanje ili nestalni trenutak, uvijek je bilo zagonetka. Ljudima se u svojoj pojavnosti predstavljalo u dva obličja: s jedne strane kao vrijeme kretanja i protočnosti koje sve nosi u svome koritu iz kojega mu nitko ne može izmaći, a s druge kao mogućnost da u prolaznosti kronosa ipak ljudi uhvate koji sretni trenutak - kairos, te tako nađu utjehu pred prolaznošću koja nikome ne prašta. Uza sve napore, ljudima ipak nije polazilo za rukom biti gospodarima vremena. Kronos je bio snažan i dominantan, uvijek iznad ljudske moći i vlasti, a kairos je bio neuhvatljiv i nestalan,

${ }^{6}$ Kronos je bilo vrijeme povezano s gibanjem, te je tako i Platon povezao rađanje vremena s nastajanjem fizičkoga svijeta (univerzum), definirajući ga kao pokretnu sliku vječnosti, to jest kao odvijanje onoga 'jest' kroz 'bijaše' i 'bit će'. Aristotel će pak proučavati tijesnu povezanost vremena s gibanjem i mjerom, te će od njega i doći znamenita definicija da je "vrijeme broj gibanja u odnosu na prije i poslije«. Produbljujući pojam mjere, zaključit će, jer su um i duša u stanju mjeriti, da je nemoguće postojanje vremena bez postojanja duše. Također vidi SIPIORA 2002: 1-23.

7 Autorica podrobno istražuje ova dva pojma, njihov nastanak, mitološku pozadinu i značenje. Osim toga uspoređuje židovsko-kršćansko poimanje vremena s antičkim ističući kako određene sličnosti, tako i dužne razlike. 
te je redovito izmicao ljudskoj ruci. Štoviše, vrijeme je nadmoćno jer ima snagu iznad ljudske snage, te posjeduje moć prolaznosti kojoj nitko ne može izbjeći. Zato, mišljenja su helenistički filozofi, nema čovjeka koji neizbježno nije podložan vremenu, to jest vječnim zakonima kojima je podložan cijeli svemir. ${ }^{8}$ A ovi zakoni su upravljali vremenom u njegovim ciklusima kojima nijedan čovjek nije mogao izmaći, te je sva mudrost antičkoga čovjeka bila u tome da prihvati ritam vremena i da mu ne pokušava umaći.

\subsection{Biblijsko poimanje vremena}

Biblijsko je iskustvo vremena bilo ponešto drukčije, premda su se i svetopisamski autori služili istim pojmovima, napose novozavjetni koji odreda pišu grčkim jezikom. Pojam kairos pojavljuje se nekoliko stotina puta u Svetom pismu, no u sasvim drukčijem kontekstu i značenju u odnosu na njegovu helenističku uporabu. I Stari zavjet, naime, sukladno općem ljudskom iskustvu, poznaje dvije dimenzije i dva vida vremena: jedno kojim ravnaju prirodni ciklusi (kozmičko vrijeme) i drugo koje se odvija u događajima (povijesno vrijeme). Zajedničko je, međutim, da Bog oboma jednako ravna i upravlja ih $\mathrm{k}$ istome cilju (LÉON-DUFOUR 1980: 1461). Vrlo je uočljivo također da su i novozavjetni autori prihvatili prvenstveno uporabu pojma kairos, premda ne $\mathrm{u}$ identičnom značenju s njegovom profanom uporabom. S druge pak strane egzistencijalno odlučujuća vremenska određenja pokrivena su u biblijskoj uporabi terminima dan i čas (hemera i hora). Nadalje, tim pojmovima pridodan je termin eon, vrijeme koje ima dimenziju protežnosti i naglašava trajanje. A kako u pluralu označava naglašenu duljinu određenoga vremenskog perioda, tako se koristi i kao oznaka za vječnost (PEHAR 2014: 54-55).

Kršćani u kasnoj antici, razvidno je, nemaju neko svoje vrijeme koje drukčije protječe od vremena u kojemu žive drugi ljudi, niti imaju druge izraze za pojam vremena. Prije svega, jer vjeruju u Boga koji je ne samo u doticaju s vremenom i stvoritelj je vremena, već vjeruju u Boga koji je kao čovjek ušao u ljudsko vrijeme, oni semantički obogaćuju grčke pojmove kojima se služe njihovi suvremenici, čime su utjecali na kakvoću shvaćanja temporalne stvarnosti. Štoviše, svojim jedincatim pristupom, shvaćajući vrijeme pozitivno kao »način na koji stvorenje participira na vječnosti Božjoj« (Teološki rječnik 1992: 662), doprinijeli su da se izmire grčki kronos i kairos kojima će Bog, gospodar

8 Na poseban način je stoička filozofija držala da svime upravljaju nepromjenjivi vječni zakoni, te da je mudrac onaj tko živi u suglasju s istima (usp. IOPPOLO 2006: 11105-11109). 
vremena i vječnosti, oduzeti moć, a svu njihovu snagu pretvorit će u povijesno-spasenjske sadržaje usmjerene prema vječnosti. Vjerovali su da je Stvoritelj vremena svojim milosnim zahvatom u vrijeme učinio da se pojavi punina vremena po Isusu Kristu (usp. Gal 4,4), a on je potom učinio da se nakon njegova otkupiteljskoga djela rijeka vremenitosti počne ulijevati u vječnost.

Zahvaljujući Božjoj prisutnosti u vremenu, biblijski čovjek, a jednako tako i kršćanin, više nema potrebu niti bježati iz vremena, niti se poistovjetiti s njegovim ciklusima i ritmom, već, naprotiv, koristi svaki trenutak kao milosnu prigodu spasenja, čime u konačnici odnosi čudesnu pobjedu nad vremenom. Osim toga, u vremenskim ciklusima prepoznat će stvoriteljsku mudrost koja sve uređuje, a ne slijepu silu prirode koja ugrožava ljudski život i dokida njegovu slobodu. U takvom kontekstu jedan od povlaštenih trenutaka pobjede nad vremenom bit će molitva kojom će se kršćani služiti za ostvarenje iznimnoga zajedništva s Gospodinom, te vratima koja vode u vječnost. Živeći molitvu kao iskorak od zemlje do neba, iz vremena u vječnost, kršćani će shvatiti njezinu nezamjenjivu važnost, jer će im molitva u ritmu vremena postati blagoslovom po kojemu dolaze do vječnosti.

\section{OBILJEŽJA MOLITVE PRVIH KRŠĆANA}

Budući da je proces o kojemu govorimo započeo s Isusom i prvom kršćanskom zajednicom, neophodno je poći od molitvenoga svjedočanstva prvih kršćana koje će biti u temeljima oblikovanja liturgije časova. U začecima toga procesa stoji Isusov osobni primjer molitve, ${ }^{9}$ kao i upute o molitvi koje daje apostolima, a oni potom vjerno i dosljedno prenose vjernicima posvuda gdje budu širili navještaj Radosne vijesti. Gdje god su se osnivale kršćanske zajednice, bile su zajednice molitve, premda način molitve nije bio istovjetan u svakoj zajednici, pa je zato važno pratiti tijek razvoja molitve od apostolskih vremena do benediktinskoga monaštva, jer će Benediktovo Djelo Božje postati univerzalno prihvaćenom molitvom zapadnoga kršćanstva.

\subsection{Molitva u apostolskoj zajednici}

Što se tiče molitve u apostolskoj zajednici, u ovom radu nam nije cilj propitivati sve sadržajne značajke, već više pozornosti posvetiti formalnom vidu

9 Apostoli su od Gospodina primili i primjer molitve, no ovdje nije mjesto o tome podrobnije razglabati. O Isusovu molitvenom životu vidi više u ASTI 2007: 510-513. 
i načinu same molitve. S obzirom na formalni vid molitve prvih kršćana, uočljivo je da postoje tri temeljna obilježja koja su usvojili i prema kojima su težili: molitva je bila neprekidna, zajednička (crkvena) i biblijska. Upravo ova obilježja bit će presudna za oblikovanje liturgije časova u kasnijim vremenima, jer će sva tri biti utkana u nju kao njezina bitna svojstva.

S obzirom na neprekidnu molitvu, to jest na potrebu da kršćanin moli bez prestanka, sam Gospodin je, kako prenosi sveti Luka u svom Evanđelju, na to poticao svoje učenike: »Kaza im prispodobu kako valja svagda moliti i nikada ne sustati« (Lk 18,1). Na tragu toga će, dvadesetak godina nakon Gospodina, sveti Pavao ${ }^{10}$ poučavati vjernike Crkve u Solunu: »Bez prestanka se molite! « (1 Sol 5,17). Molitva, dakle, za prve kršćane nije bila izolirani kreposni čin pobožnosti ovisan o ljudskoj potrebi ili zahtjevu pred Bogom, već je težila $\mathrm{k}$ tome da postane habitus - trajno duhovno stanje u kojemu živi kršćanska duša.

Osim toga, prvi kršćani nisu njegovali samo privatni način molitve u vlastitoj sobi, ${ }^{11}$ već su, po preporuci Gospodnjoj, njegovali i zajedničku molitvu: »Nadalje, kažem vam, ako dvojica od vas na zemlji jednodušno zaištu što mu drago, dat će im Otac moj, koji je na nebesima. Jer gdje su dvojica ili trojica sabrana u moje ime, tu sam i ja među njima« (Mt 18,19-20). Ne samo da je molitva zajednice bila na neki način »jača« od osobne molitve, već je molitva bila razlog okupljanja Crkve u kojoj je Isus jamčio svoju prisutnost. Molitva se ticala same biti Crkve, zajednice Kristovih vjernika, te je bilo nedopustivo i pomisliti da može postojati kršćanska zajednica koja ne njeguje molitvu. Crkva je, dakle, po svom opisu i biti bila zajednica molitve okupljena oko Isusa, te se molitvom učvršćivala u zajedništvu, kako s Gospodinom tako i u međusobnom zajedništvu svih članova Crkve. Stoga ne čudi da sveti Luka u Djelima apostolskim ističe kako su prvi kršćani u jeruzalemskoj Crkvi, između ostaloga, bili postojani i u molitvi: »Bijahu postojani u nauku apostolskom, u zajedništvu, lomljenju kruha i molitvama« (Dj 2,42).

Uza sve rečeno, bilo bi važno još precizirati da su kršćani zajedništvo molitve njegovali u dva povlaštena ambijenta. Za jeruzalemske kršćane povlašteno mjesto molitve bio je Hram kao najsvetije i najčasnije bogoštovno

${ }^{10}$ Više o načinima i sadržajima molitve u Pavlovim poslanicama i zajednicama vidi u PITTA 2007: 142-154.

${ }^{11}$ Što se tiče osobne molitve, dovoljno se prisjetiti Isusovih riječi kojima potiče učenike da ne mole kao licemjeri koji mole da se pokažu drugima, već da mole u skrovitosti: »Ti naprotiv, kad moliš, uđi u svoju sobu, zatvori vrata i pomoli se svomu Ocu, koji je u skrovitosti. I Otac tvoj, koji vidi u skrovitosti, uzvratit će ti« (Mt 6,6). 
mjesto, a s druge strane to su bile obiteljske kuće u kojima su se okupljali na euharistijsko slavlje, ili, kako ga sveti Luka zove, »lomljenje kruha«. Jer neposredno nakon Pedesetnice i silaska Duha Svetoga na apostole i okupljenu zajednicu, dok su još prvi kršćani imali snažne veze sa židovstvom iz kojega su potekli Gospodin i svi apostoli, te dok još nisu započeli naviještati izvan Jeruzalema, sveti će Luka reći da su svaki dan »jednodušno i postojano hrlili u Hram, u kućama bi lomili kruh te u radosti i prostodušnosti srca zajednički uzimali hranu « (Dj 2,46). Važna je informacija također da su apostoli odlazili u Hram prema židovskom običaju na određene molitvene ure (usp. Dj 3,1), jer iz toga zaključujemo da su i nakon Gospodinova uzašašća k Ocu još uvijek prakticirali hramske molitve pobožnih Židova. To znači da nisu odbacili ni zanemarili židovske molitve i hramsku liturgiju niti nakon što ih je Gospodin naučio moliti molitvu koja je bila ekskluzivno njihova.

Činjenici o sudjelovanju jeruzalemskih kršćana u hramskoj liturgiji valja pridodati i to da je Psaltir, korišten kao službena knjiga pjesama i molitava u bogoštovlju drugoga hrama, sačinjavao okosnicu hramskih molitava (LORENZIN 2001: 22-24). ${ }^{12}$ Dokaz je to, ali i vrlo logična istina, da su židovske molitve i hramska liturgija bile prožete duhom Svetoga pisma, bez obzira jesu li se molili i pjevali psalmi ili su se upotrebljavale druge molitve. Jer se ne može izgubiti iz vida da pobožni Židov (kršćanin također!), svjestan uzvišenosti molitve i bogoštovlja, nije sebi uzimao za pravo koristiti osobne, već isključivo službene molitvene obrasce odobrene u zajednici. To je bilo nedvojbeno jer je bila riječ o svetopisamskim nadahnutim molitvenim tekstovima od kojih nitko nije mogao pronaći boljih i prikladnijih za razgovor s Bogom. ${ }^{13} \mathrm{~A}$ o povezanosti molitve prvih kršćana i Svetoga pisma postoji svjedočanstvo kod sv. Pavla kad veli: »Psalmima, hvalospjevima, pjesmama duhovnim od srca pjevajte hvalu Bogu!« (Kol 3,16). Pavao će, dakle, iako je u tom trenutku židovstvo već otvoreno odbacivalo kršćansku vjeru i progonilo njega, implementirati židovski običaj pjevanja psalama i himana u običaje svojih zajednica diljem svijeta, te će time Sveto pismo i svetopisamske molitve nedvojbeno sačinjavati temelj molitve rane Crkve.

${ }^{12}$ Autor čak navodi koji su se psalmi pjevali u pojedino doba dana u Hramu, te ističe kako ipak nisu svi psalmi nastali u hramskom ambijentu. Prema njegovu mišljenju psalmi su ušli u kršćansku liturgiju tek krajem 2. stoljeća (usp. LORENZIN 2001: 22-24).

${ }^{13}$ Dokaz za to je i svjedočanstvo svetoga Ciprijana, koji, tumačeći Gospodnju molitvu (br. 3), lijepo reče da je »ugodna i prisna molitva kada Boga molimo njegovim i Kristovu molitvu uzdižemo do njegovih ušiju « (CIPRIJAN 1987: 134). Isto pravilo koje je vrijedilo za Gospodnju molitvu vrijedilo je i za ostale svetopisamske tekstove. 
No, uz kontinuiranu uporabu Psaltira i drugih svetopisamskih molitava Isusovi učenici su imali i jednu posebnu molitvu koju su njegovali kao neprocjenjivo blago. Riječ je o molitvi kojoj ih je poučio sam Gospodin, te je zato i dobila naziv »Gospodnja molitva« ili čak samo »Molitva«. Ona je za kršćane bila molitva par excellence jer je poučavala najispravnijem sadržaju kojim je bilo ne samo zakonito već i poželjno iskati od Boga. Isus je ovu molitvu dao svojim učenicima na njihov zahtjev (usp. Lk 11,1), te ih je time poučio najvažnijemu redoslijedu moljenja, bez korištenja mnoštva riječi, ali sadržajno potpuno u skladu s ispravnom pobožnošću. Ako su jeruzalemski kršćani javno prakticirali molitvu Psalama i hramsku liturgiju zajedno s drugom židovskom braćom, onda su Molitvu Gospodnju prakticirali osobno te u molitvenom zajedništvu po kućama kada su »lomili kruh«.

\subsection{Molitva u postapostolskom vremenu}

Ali ne samo da je prva kršćanska zajednica bila zajednica postojane molitve, već je ona postala prototip prema kojem su se oblikovale i sve buduće zajednice i naraštaji kršćana. Kršćani kasnijih vremena držat će svojom obvezom nasljedovati život apostolske zajednice i sve uredbe koje je ona ostavila, budući da je po mnogočemu bila smatrana idealnom. Napose će to vrijediti za sve bogoštovne sadržaje, ali i za pravilo međusobne ljubavi i dijeljenja dobara. Da je ova tvrdnja utemeljena, može se dokazati iz Uputa apostolskih, jednoga od najstarijih kršćanskih nekanonskih spisa. Pisac ovoga djela poziva vjernike da ne mole kao licemjeri, već da mole Gospodnju molitvu tri puta na dan. ${ }^{14}$ Kontekst ovih uputa je polemika sa židovstvom, te autor ne govori ništa o prakticiranju molitve Psalama u ambijentu u kojemu nastaje ovaj spis, no već je prije istaknuto kako je sveti Pavao njegovao molitvu Psalama, premda je bio u otvorenom sukobu sa židovskim starješinama s kojima je progonio kršćane sve dok se nije obratio. Za pretpostaviti je stoga da židovsko-kršćanski sukob nije utjecao na kršćansku molitvenu praksu i običaje.

\footnotetext{
${ }^{14}$ Usp. Upute apostolske 2010: 23. Prema mišljenju znanstvenika, završna redakcija ovoga spisa nastala je krajem 1. stoljeća (RORDORF 2006: 1400-1402). Pod pojmom licemjeri misli se na židovstvo, te je očito da je u vremenu kada nastaje tekst Uputa apostolskih u tijeku proces odvajanja kršćanstva od židovstva, što se onda ticalo i same molitve. Kršćani se žele pokazati zasebnom zajednicom koja ne slijedi židovske obrasce, te u ovom slučaju Gospodnja molitva služi i kao pokazatelj različitosti. No unatoč potrebi da se kršćani distanciraju i pokažu različitima od židovstva, ipak neće odustati od uporabe Staroga zavjeta i molitve Psaltira.
} 
Osim osobne molitve, kao što je vjerojatno bio slučaj u Uputama apostolskim, i u prvoj kršćanskoj literaturi postoje jasne naznake da je u kršćanskim zajednicama postojala i zajednička molitva, za koju je pretpostavka stanovita organizacija i uređenje zajednice. O tome svjedoči na početku 2. st. sveti Ignacije Antiohijski u Pismu Magnežanima (VII, 1): »Kao što Gospodin, ni sam ni po apostolima, ništa nije činio bez Oca s kojim je jedno, tako ni vi ništa ne činite bez biskupa i svećenika. Niti se trudite da nešto što zasebno učinite izgleda hvale vrijedno, nego neka vam u jedno sabranima bude jedna prošnja, jedna molitva, jedan duh, jedna nada u ljubavi, u svetoj radosti koja je Isus Krist od kojega nema ništa bolje. $\ll^{15}$

Potom, sto godina kasnije, kod Tertulijana se pronalazi svjedočanstvo o propisanim molitvama (lat. orationes legitimae), pod čime se podrazumijeva jutarnje i večernje vrijeme molitve onako kako su bile propisane Zakonom i običajima. ${ }^{16} \mathrm{Uz}$ propisane molitve ovaj znameniti kršćanski pisac iz Kartage u svom spisu De oratione (XXV,1-5) savjetuje vjernicima i praksu trećega, šestoga i devetoga časa, sukladno praksi samih apostola, smatrajući kako kršćanin ne smije moliti manje od tri puta na dan, jer je dužnik Presvetoga Trojstva, Oca i Sina i Duha Svetoga. ${ }^{17}$ Otprilike iz istoga razdoblja je i Traditio apostolica, spis koji se pripisivao Hipolitu Rimskom, a koji nam daje uvid u svakodnevne molitve rimskih kršćana. Prema svjedočanstvu ovog spisa (br. 39-41) svećenici i đakoni se okupljaju svaki dan na molitvu, daju pouke onima koji su u crkvi, zajednički mole i potom odlaze na svoje svakodnevne dužnosti. Jednako tako se iziskuje od vjernika, koji god mogu, da prije svakodnevnoga posla dođu na pouke i molitvu u crkvu, te da potom prakticiraju moliti u kući o trećoj, šestoj i devetoj uri. A naravno, ni završetak dana prije spavanja ne bi smio proći bez molitve, a čak bi trebali ustati i u ponoć moliti zajedno sa svojim supružnicima. ${ }^{18}$

Premda su vremena za kršćane još uvijek bila nesigurna, ipak treba imati $\mathrm{u}$ vidu da su u gradovima postojale asketske zajednice koje su, bez daljnjega, njegovale zajedničku molitvu u crkvama, to jest na bogoštovnim mjestima. Nema sumnje da su biskupi i svećenici, te Bogu posvećene duše vršile »kanonsku« službu u crkvama, ovisno o mogućnostima s obzirom na progone $\mathrm{Cr}$ -

\footnotetext{
${ }^{15}$ IGNACIJE ANTIOHIJSKI 2010: 55.

${ }^{16}$ Više o tome usp. ADAM 1992: 262. Autor navodi i svjedočanstvo Apostolskih konstitucija koje opisuju molitvu čija struktura sliči našoj današnjoj Večernjoj molitvi.

17 TERTULLIANUS 1954: 272-273.

18 PSEUDO-IPPOLITO 1996: 137-141.
} 
kve u predkonstantinovskome razdoblju. Premda je utemeljeno pitanje koliko su svi vjernici u zajednici mogli ostvarivati ritam od pet molitvenih časova dnevno, ${ }^{19}$ ipak je sigurno bilo mjesnih crkva gdje je to bilo moguće. Napose kler i Bogu posvećene osobe molitvu su doživljavale svojom prvotnom vjerničkom zadaćom, te su molili i za one koji, zbog obveza i drugih otežavajućih okolnosti, nisu mogli sudjelovati prateći zadani cjelokupni ritam molitve.

I u Kartagi, dakle, i u Rimu postojala je praksa pet dnevnih molitvenih časova u koje su kršćani molili, bilo da je riječ o onim crkveno propisanim, bilo da je riječ o osobnim molitvama. Jedino ostaje nepoznato što se točno molilo u određene sate dana. Zasigurno vjernici su osobno molili Molitvu Gospod$n j u$, ali ostaje nepoznanica koje su se točno molitve prakticirale u Rimu u zajedništvu sa svećenicima i đakonima, to jest koje su molitve bile propisane vjernicima ujutro i uvečer u kartaškoj zajednici. Vjerujem da je izvan svake sumnje da su te molitve bile sastavljene od psalama jer su psalmi od samih početaka Crkve bili najprikladnija molitva čitana u kristološkom ključu. ${ }^{20} \mathrm{U}$ prilog ovoj tvrdnji može se dodati da će već u ovom razdoblju u kojemu nastaje Traditio apostolica i u kojem djeluje Tertulijan, u Aleksandriji znameniti Origen (185. - 254.) biti prvi autor koji će komentirati cijeli Psaltir. Ako isto tako znamo da njegova egzegetska produkcija započinje upravo Tumačenjem Psaltira (PRINZIVALLI 2000: 422), a znajući da na čelo Aleksandrijske škole dolazi godine 202., to znači da je već početkom 3. stoljeća nastao spomenuti komentar.

Doista je važno naglasiti da je molitva psalama u prvoj Crkvi imala posebnu ulogu, rezultat čega je bio usvajanje psalama kao okosnice liturgije časova,

${ }^{19}$ Još uvijek se raspravlja o tome kako je došlo do oblikovanja pet molitvenih časova i pod čijim utjecajem. Radi li se o zbrajanju dvaju molitvenih časova (ujutro i navečer) i triju časova tijekom dana, te je li se taj proces dogodio pod utjecajem židovskih molitvenih časova, napose hramske liturgije, ostaje još uvijek nepoznanica o kojoj se postavljaju različite hipoteze poradi nedostatka izravnih vrela. Ali je činjenica da je u 4. stoljeću već postojao razvijeni obrazac liturgije časova raspoređenih u pet molitvenih »trenutaka dana« (usp. FRØYSHOV 2010: 121-138). Autor također istražuje što se molilo u određene ure u 4. st. i glede toga daje neka rješenja. U svakom slučaju riječ je o pojedinim psalmima (Ps 40, 62, 90, 140), što jasno potvrđuje kršćansku uporabu Psaltira kao knjige molitve, bez obzira što se nije molilo sve psalme na sustavan način.

${ }^{20}$ Više o tome vidi PEHAR 2020: 2-6. Doista, već je u židovstvu postojalo mesijansko čitanje Psaltira, napose kada je izraelski narod ostao bez monarhije i nakon što su bili odvedeni u progonstvo (LORENZIN 2001: 552-554), pa je tim jednostavnije bilo kršćanskoj zajednici preuzeti Psaltir razmatrajući ga kroz istu mesijansku prizmu. Razlika je bila jedino u tome što kršćani nisu čitali Psaltir kroz optiku iščekivanja Mesije, već kroz onu kristološku, smatrajući da je Krist obećani Mesija koji je ispunio psalamska proročanstva. 
jer su psalmi za prvu kršćansku zajednicu imali osobito kristološko značenje (GRIBOMONT 2008: 4664-4667). Njihov sadržaj i poruku držali su govorom Krista koji s jedne strane govori iz perspektive svoga božanstva, a s druge strane govori kao utjelovljeni Bog koji je solidaran s ljudima u svemu, te time i u patnji, muci i smrti. Pogotovo što je molitva psalama bila kao pjesma lako usvajana i memorirana, imala je povlašten položaj za kršćanina koji je u njoj mogao pronaći i sebe, ali ne samo u ljudskoj dimenziji već kroz lik Krista, Boga i čovjeka. Tako kršćanska molitva psalama nije imala samo kozmološko ni samo antropološko značenje da bi slavila ritam prirode ili dozivala u pamet ljudske situacije, već je bilo daleko bitnije da je u psalmima slavila Krista koji je bio savršeni odgovor na stvaranje, ali i na antropološke probleme i spasenjske upite svakoga čovjeka. Osim toga, Krist je bio put do Boga, te je onda kristološkim slavljenjem, to jest molitvom Psaltira, Crkva u istom činu odgovarala na sve zahtjeve koji su bili pred njom kako glede potrebe da se izdigne iznad »cikličkog vremena « $\mathrm{i}$ iz zatvorene povijesti, tako isto i glede potrebe da bude trajno uronjena u molitvu slaveći cjelovito Boga svojim životom.

Ako potom Frøyshov (FRØYSHOV 2010: 126-130) svjedoči da je u različitim zemljopisnim područjima u 4. stoljeću (Kapadocija, Palestina) postojala praksa za jutarnju i večernju molitvu moliti određene psalme, onda valja zaključiti da takva praksa nije nastala ni iz čega, već se zacijelo naslanjala na prethodnu tradiciju živu u kršćanskim zajednicama. To vrijedi s obzirom na broj od pet molitvenih časova, ali isto tako i za molitvene sadržaje kojima su psalmi bili temelj. Zato je Psaltir, smatran zbirom i sažetkom (lat. summa et compendium) cijele biblijske poruke, već od najranijih vremena postao za

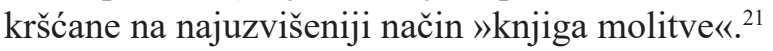

\section{MONAŠTVO U TRAŽENJU ODGOVORA}

Prihvaćanje psalama kao sastavnice liturgije časova završeno je procesom u kojem je svoj obol dao monaški pokret koji se intenzivno razvijao od 4. stoljeća kada je kršćanstvo dobilo slobodu. Može se smatrati da je time dovršen proces stvaranja liturgije časova i oblikovanje izričaja njezinih sastavnica. Opravdani zahtjevi da molitva ritmizira vrijeme kršćanina, te da se pravim

${ }^{21}$ Proces usvajanja Psaltira kao molitve Crkve bio je olakšan time što je već u židovstvu Psaltir bio službena liturgijska knjiga (RAVASI 1988: 1411), gdje je recitiranje psalama odgovaralo liturgijskoj službi premda bez kultnih žrtvenih procedura (LORENZIN 2001: 550). 
načinom molitve razriješi izazovna zagonetka vremena, pronašli su u monaškom pokretu svoj cjeloviti odgovor kojim se zaokružio proces sazrijevanja i strukturiranja molitve časova. Mnogi od pionira i velikana monaškoga života preveli su evanđeoske poticaje na molitvu u odredbe koje su davali braći u zajednicama kao konkretno i precizno pravilo.

S pravom su stoga teolozi mišljenja da su najzaslužniji za razvoj liturgije časova bili upravo monasi kojima je molitva bila prvotni zadatak (TENŠEK 2003: 82). Monasi su osjećali nasušnom potrebom i osnovnom dužnošću dosljedno odgovoriti na Gospodinove pouke vezane uz molitvu, bilo da ih je izrekao on osobno ili da ih je dao po apostolima. Osim toga, monasi su i najintenzivnije osjetili problem novih okolnosti i vremena u kojem se Crkva našla u vremenu slobode, ali i vremenu u kojemu je nestankom društvenoga pritiska i progona izostao apostolski žar i vjerodostojno svjedočenje mnogih kršćana (DATTRINO 1984: 13), te su se kršćani sve više počeli suobličavati mentalitetu društva u kojemu su živjeli. Mnogi, naime, nisu više ni pravili pravi odmak od svijeta, premda je sveti Pavao glede toga davno izrekao upozorenje i vapaj: »Ne suobličujte se ovomu svijetu, nego se preobrazujte obnavljanjem svoje pameti da mognete razabirati što je volja Božja, što li je dobro, Bogu milo, savršeno.« (Rim 12,2). ${ }^{22}$ Dakle, kršćani su bili pozvani ne suobličavati se ni svijetu ni vremenu u kojemu žive, nego radije da se obnavljaju suobličavajući se onom budućem eonu, to jest vječnosti. Kao najsvjesniji članovi Crkve, monasi su na se preuzeli zadaću radikalno odgovoriti na taj izazov, spremni kao novi mučenici umirati na drukčiji način za evanđeoske vrijednosti. Pri tome su, stavljajući naglasak na potrebu obraćenja, pokore i askeze ispunjavali još jedan Pavlov poticaj: »Iskupljujte vrijeme, jer dani su zli!« (Ef 5,16).

\subsection{Benediktinska duhovnost i izazov vremena}

S obzirom pak na oblikovanja liturgije časova na Zapadu, ona dolazi do svoga vrhunca upravo sa svetim Benediktom koji će Crkvi dati model molitve koji je ostao sve do danas, uz nužne prilagodbe uzrokovane promjenama okolnosti života. Božja riječ bila je svetom Benediktu vrelo nadahnuća, te je on kao brižni otac skrbio oko usvajanja duha molitve i širenja molitvene prakse u Crkvi. S druge pak strane monaški pokret bio je i snažna reakcija na stanje

${ }^{22}$ Te Pavlove preporuke Rimljanima znakovite su pogotovo što se za riječ svijet u grčkom izvor-

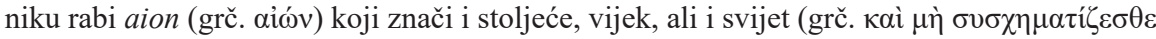

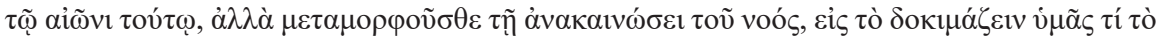

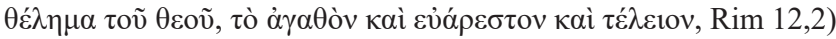


u Crkvi i u društvu s obzirom na mlakost u koju su zapali mnogi vjernici u vremenu slobode i slobodnoga djelovanja Crkve od Konstantina nadalje.

\subsubsection{Od cikličkoga vremena do cikličke molitve}

Sveti je Benedikt bio svjestan gorućega poziva kršćanima da s ozbiljnošću upravljaju svojim vremenom, kao i napasti da se monah prepusti proizvoljnom načinu života. Zato je svojim monasima dao jasne koordinate prostora $\mathrm{i}$ vremena potičući ih da »izbjegavaju djela svijeta« (IV, 20; PB 2008: 69). ${ }^{23} \mathrm{U}$ tome se sastojala bit monaškoga poziva koji se drugim riječima izricao kao fuga mundi, tj. »bijeg od svijeta«. Ako je monah i mogao pobjeći od svijeta zatvarajući se iza samostanskih vrata, nije mu međutim bilo moguće pobjeći od vremena, koje je svakoga pratilo i sustizalo gdje god bio. Zato je i Benedikt u svome pravilu postavio zahtjev, ne da se bježi od vremena ili iz vremena, već da se »iskupljuje vrijeme« živeći svetim životom sukladno vrlo preciznim zahtjevima koji se tiču vremenskoga ritma. Monah je trebao vrijeme pretvoriti u milosni kairos prateći njegov zahtjevni ritam iz dana u dan. Ako je dan bio sastavljen od 24 sata, Benedikt nastoji pronaći pravi ritam, a i pravu aktivnost, kojom će zagospodariti vremenom. Jednako vrijedi i za tjedne i za godine koji se također ponavljaju ciklički. No, Benedikt u cikličko kozmičko vrijeme molitvom i redom (Djelo Božje, rad, čitanje, blagovanje i spavanje) uvodi novi kvalitativni sadržaj, tako da ga pretvara u konstituirano i koncentrirano vrijeme (OGLIARI 2014: 14). Na taj način monah odnosi pobjedu nad kozmičkim i cikličkim vremenom, jer ga je presložio u novu strukturu kojoj je on odredio cilj, a sukladno biblijskom poimanju vremena to je vječnost. Povijest kao takva nije podvrgnuta zakonu vječnoga vraćanja, jer o njoj odlučuje Božji naum koji se u njoj odvija i očituje. Bog se time predstavlja gospodarem povijesti, a očitujući se u povijesti on svojom prisutnošću sakralizira povijesno vrijeme, te ono postaje vrijeme spasenja, a povijest postaje svetom poviješću (LEON-DUFOUR 1980: 1461-1465).

Vrhunac procesa sučeljavanja i izmirivanja s vremenom sadržan je u Benediktovu Pravilu kojem je sažetak krilatica ora et labora. Benedikt, doista, u Pravilu pridaje veliku važnost molitvi posvećujući joj više poglavlja (od 8. do 20.). I dok ne daje nikakvo teološko ili duhovno tumačenje molitve, određuje ipak potankosti s obzirom na način slavljenja, npr. kako se molitva oglašuje i kojim se redoslijedom imaju moliti psalmi u pojedinim časovima (MONAH

${ }^{23}$ Više o značenju pojma svijet (lat. saeculum), kao i o značenju ove izreke u kontekstu Pravila vidi u OGLIARI 2014: 11-14. 
DOROTEJ 2006: 236-237). ${ }^{24}$ Benedikt tako propisuje kako se služba Božja obavlja noću i koji se psalmi pjevaju (8. i 9. poglavlje), kako se obavlja noćno bdjenje običnim danom i nedjeljom (10. i 11. poglavlje), te na blagdane svetaca (14. poglavlje), kako se slavi Jutarnja nedjeljom i u obične dane (12. i 13. poglavlje), u koje se vrijeme pjeva Aleluja (15. poglavlje). Posebne upute daje za molitvu Djela Božjega danju prema rasporedu časova (16. poglavlje), te objašnjava koliko se psalma pjeva o Prvom, Trećem, Šestom, Devetom času i za Večernju (17. poglavlje). Također su detaljne odredbe o redoslijedu kojim se mole psalmi (18. poglavlje), te sve skupa završava odredbom o ponašanju kod pjevanja psalama (19. poglavlje) i o smjernosti kod molitve (20. poglavlje).

Potreba da molitva oblikuje i ritmizira cijeli dan monaha u Pravilu je pretočena tako u odredbu o zajedničkoj molitvi liturgije časova, sukladno uzusima prve kršćanske zajednice, te Crkve kao takve. Što se tiče dnevnoga ritma, molitva je raspoređena u sedam dnevnih časova, što je nadahnuto psalmom 119,164: »Sedam puta na dan tebe hvalim. « A tih sedam puta kada se Boga hvali molitvom jest: Jutarnja, Prvi, Treći, Šesti i Deveti čas, te Večernja i Povečerje, čemu se pridodaje kao osmi i jedan noćni čas. Evo kako to Benedikt obrazlaže u svom Pravilu: »Kao što kaže Prorok: 'Sedam puta na dan tebe hvalim.' Taj posvećeni broj sedam ispunjavamo tako da dužnosti svoje službe obavljamo Jutarnjom, Prvim, Trećim, Šestim i Devetim časom, Večernjom i Povečerjem; jer o tim molitvenim dnevnim časovima Prorok veli: 'Sedam puta na dan tebe hvalim'. O slavljenju noćnoga Bdjenja taj isti Prorok kaže: 'O ponoći ustajem da te slavim.' « (XVI, 5; PB 2008: 88). ${ }^{25}$ Ova struktura molitve liturgije časova koju je dijelom prihvatio iz mogućih vrela, a dijelom sam razradio sveti Benedikt, ostat će dugi niz stoljeća nepromijenjena, a i danas u molitvenoj praksi Crkve uz dužne varijacije. ${ }^{26}$

${ }^{24}$ Autor ističe kako je u doba svetoga Benedikta moljenje liturgijskih časova bilo još u formiranju i podložno onodobnom shvaćanju i računanju vremena, koje nije bilo ujednačeno. Danju se računalo pomoću sunčanoga sata, a noću pomoću klepsidre ili pješčanoga sata, odnosno prema dužini izgaranja svijeće ili prema zvijezdama.

${ }^{25}$ Više o tome vidi PENCO 1983: 74-76.

${ }^{26}$ Prema reformi Psaltira Drugoga vatikanskoga sabora Crkva ne iziskuje više od pastoralnoga klera da izmole sve psalme u tjedan dana, kao što je sveti Benedikt oblikovao molitvu, već je Psaltir rasporedila u četiri tjedna, pri čemu ostaje smisao ove molitve da se ipak u jednom kraćem razdoblju izmole svi psalmi. Tako je Crkva tjedni ritam prebacila na mjesečni, poštujući ipak prirodnu cikličnost koju je Gospodin usadio u vrijeme. Druga razlika je u tome što za pastoralni kler nema noćnoga Bdjenja, a isto tako je, u odnosu na Benediktov dnevni ritam, izbačen i Prvi čas, no zato je uveden Pozivnik i Služba čitanja. Osim toga klerici danas 
Osim što je riječ o vjernom odgovoru na svetopisamski poticaj, valja istaknuti da Benedikt inzistira na simbolizmu broja sedam, pa ga zato i zove "posvećenim brojem sedam «, lat. septenarius sacratus numerus. Kad za sedam kaže da je posvećen, onda misli na simboličko značenje toga broja u Svetom pismu i kršćanskoj tradiciji, ničime ne dovodeći njegovu sakralnost u vezu s iznankršćanskim magijskim tumačenjima. Simbolizam broja sedam doziva u pamet savršenstvo, te će stoga Benedikt u znaku broja sedam urediti molitve časova svojih monaških zajednica.

Nadalje, nije samo cijeli dan posvećen Bogu neprekidnom molitvom koja se odvija u sedam molitvenih časova, već je posvećen ujedno i tjedan prirodnoga ciklusa vremena, kao i godina. Zato monah u jednom tjednu izmoli cijeli Psaltir, počevši od prve Večernje u nedjelju, koja je početak dana i daje smisao kako molitvi tako i radu, a tijekom godine slavi sva otajstva koja je Bog očitovao za spasenje ljudi, napose uskrsno otajstvo (PENCO 1983: 76-77). Benedikt je, dakle, kod svoje subraće inzistirao da kao monasi trebaju izmoliti svih 150 psalama, to jest cjelokupni Psaltir, u jednom tjednu: »Monasi, naime, koji tjedno ne izmole čitav Psaltir i uobičajene hvalospjeve, pokazuju da vrlo nemarno vrše svoju službu, kad čitamo da su naši sveti Oci izvršavali u jednom danu ono što bismo mi nemarni morali obavljati barem tjedno « (XVIII, 24-25; PB 2008: 92). A molitva cijeloga Psaltira označavala je sadržajnu cjelovitost monaške molitve o čemu će još biti govora.

\subsubsection{Djelo Božje kao povijest spasenja}

Iz do sada rečenoga jasno je zašto u Benediktovu Pravilu molitva ima izuzetno mjesto, a nadasve zajednička molitva liturgije časova, nazvana Djelo Božje. Benedikt je s pravom htio da molitva liturgije časova zauzima najveći i najbolji dio monahova vremena, te da monah u nju uloži cijeloga sebe i svu svoju snagu. Zato je rasporedio molitvu Djela Božjega imajući u vidu sate u danu, te usklađenost s kozmičkim redom godišnjih doba, kako bi se monaški život pretvorio $\mathrm{u}$ veliku harmoniju, to jest »glazbenu kompoziciju« ${ }^{27}$ Molitvom psalama razmatrao je povijest spasenja, te je za njega molitva postajala

nisu dužni moliti sva tri dnevna časa (Treći, Šesti, Deveti), već mogu izabrati jedan od njih, ovisno o obvezama.

${ }^{27}$ Više o tome vidi u OGLIARI 2014: 14-15. Autor ističe da monah, prilagođavajući se kozmičko-prirodnom ritmu dana, tjedana i mjeseci, sudjeluje $u$ harmoniji koju je Bog upisao u svemir, a Božja harmonija uzrokuje »muzikalizaciju« monaškoga života. Njegov život ipak nije samo kruženje, već se postupno uzdiže prema vječnosti. 
bitnom sastavnicom vlastite povijesti spasenja. No, u tom slučaju, jer je Psaltir cjelina sastavljena od 150 psalama, monah je imao zadaću cjelovito razmatrati povijest spasenja, što je pretpostavka i cjelovitoga spasenja kojemu teži.

Monahinja Ana Maria Canopi će zbog toga istaknuti da uz usklađenost s kozmičkim redom, monah treba skrbiti o povezanosti s Kristovim vazmenim otajstvom: »Poredak i sam način na koji se odvija liturgija časova - u kojem se naime izmjenjuju pjesma, slušanje i trenutci tišine - prema ritmu dnevnih i noćnih sati, prema liturgijskim vremenima i godišnjim dobima, označava usku podudarnost između ritma vremena i čovjekova životnoga ritma, čiji život mora biti poput rijeke koja teče u vječnost pomoću 'disanja' koje je molitva. Na onaj način na koji je to opat Antonio preporučivao svojim učenicima u pustinji: Christum semper respirare. Budući da je Krist pravi dan, dok se na svom ovozemaljskom putu ravnamo prema satima prirodnoga svjetla, vidljivoga našim tjelesnim očima, idemo ujedno prema danu koji je sam Krist i bivamo uvedeni u svjetlo koje ne pozna zalaza koji sada možemo vidjeti samo očima vjere. Sat što ga diktira Sunce svojom putanjom je naime za nas znak pravoga svjetla, koje je Krist; dakle svakoga dana, slaveći Opus Dei, mi $\mathrm{u}$ procesiji idemo za Jaganjcem, prelazeći iz sata u sat kao s brda na brdo u kraljevstvo nebesko. Na taj način čas ovoga svijeta prebacujemo u vječnost, unosimo svoju hvalu, koja odzvanja u vremenu, u hvalu koja se doista neprestano razliježe u zboru nebeskog Jeruzalema« (CANOPI 2011: 97).

Ako za ikoga možemo reći da je osjećao kao vlastitu obvezu ispunjavati svetopisamsku odredbu o posvećivanju vremena, onda su to bili monasi koji su se zauzimali oko vjernoga vršenja evanđeoskih savjeta i time se izdizali iznad stvarnosti i logike kronološkoga vremena. Jedno od povlaštenih sredstava izdizanja izvan i iznad logike kronološkoga vremena bila je molitva koja je molitelja stavljala u izravan doticaj s vječnim Bogom, po čijem Sinu je došla molitva i poziv na molitvu. Molitva je omogućivala participiranje u njegovoj vječnosti i svim ostalim atributima i krepostima koje iz njega izviru. Monah je tako ulazio u ritam Božjega vremena koje je bilo sasvim drukčije od ljudskoga vremena. I ovaj ritam bio je dvojak: s jedne strane je mijenjao ritam i tijek povijesnog vremena, jer povijest nije više bila samo ljudska povijest, već se pretvarala u povijest spasenja, a s druge strane je bio promijenjen i ponavljajući ciklus kozmičkoga vremena. To jest, bilo bi preciznije reći, i povijesni i kozmički ciklus bio je prožet otajstvom Boga koji je i jednom i drugom ciklusu davao drukčiji smisao i perspektivu. Cikličko vrijeme pretvorilo se u ciklus kojim se slavi Boga i njegovu prisutnost u svijetu, a povijesno vrijeme se pretvorilo u povijest spasenja. 
Stoga se danas u teologiji kaže da posvećivanje vremena daje specifični smisao liturgiji časova. I doista, bitna datost liturgije časova je njezina povezanost s vremenom i to iznutra. Liturgija časova ukazuje na važnost trenutka $u$ kojemu živimo, te nam ne oduzima vrijeme, već nas oslobađa za vrijeme i povezuje s vječnošću. Smisao ove molitve je posvećivanje cjelokupnoga čovjekova vremena, a njezin ritam čovjeku pomaže razumjeti da živi u otkupljenom vremenu. Stoga vrijeme nije samo marginalni, već je ključni sadržajni i interpretativni element liturgije časova (CRNČEVIĆ; ŠAŠKO 2009: 526-528).

Molitva liturgije časova je, nema sumnje, izvrstan primjer uz pomoć kojega se shvaća kako su se kršćani odnosili prema zagonetki i tajni vremena koje je za njih, po Bogu koji se uprisutnio u vrijeme, postalo otajstvo. Monasi nisu sebi umišljali da mogu zagospodariti nad njim, jer ih je kao pojava nadilazilo, niti su imali potrebu boriti se protiv njega, jer bi to bila borba protiv vjetrenjača, budući da su i sami živjeli u vremenu. Jedina ispravna opcija bila je pretvoriti ga u spasenjsku prigodu - kairos u kojem se događa susret s Bogom. $\mathrm{Na}$ taj način su vrijeme pretvorili u saveznika i iskoristili za svoj cilj. Polazeći od Kristove prisutnosti u vremenu i njegova nauka na zemlji monasi nisu više nastojali oko duljine dana, već oko kakvoće duhovnoga života. Nisu bili vlasni promijeniti ritam vremena koji je Gospodin zadao, ali ih je vjera učila kako ga iskoristiti za posvećenje vlastitoga života. Ne čudi stoga da su upravo oni razvili najprecizniju strategiju i tehniku upravljanja vremenom. Njih će zbog posebnoga načina kojim su provodili vrijeme smatrati istinskim filozofima koji žive i promiču autentičnu kršćansku filozofiju (PENCO 1993: 13-14). A »filozofska tehnika« kojom su se služili da ostvare svoje ciljeve bila je molitva časova i kontemplacija. Monaško poimanje vremena, međutim, bilo je u potpunosti biblijsko, a ne svjetovno (helenističko) zbog čega su monasi ulagali izniman napor da vrijeme kao pojavu i okolnost ljudskoga života, molitvom i duhovnim angažmanom, pretvore u milosni kairos spasenja, pri čemu će im molitva časova biti najdragocjenije »priručno« sredstvo.

\subsection{Benediktov odgovor na poziv na neprekidnu molitvu}

Molitva je, sasvim je neupitno, imala veliku važnost u životu monaha, ${ }^{28}$ pa je zato uz ostale karakteristike zadobila dimenziju trajnosti, neprekidnosti.

${ }^{28}$ Molitva kao takva imala je višestruko značenje u životu monaha, no osobito bi se mogle istaknuti tri važne točke: molitva kao molba Bogu za ono što je prikladno, uzdizanje duha k Bogu i razgovor s Bogom (LEVKO 2000: 2). 
Valja jasno reći da poimanje neprekidne molitve nije bilo jednoznačno u prvoj Crkvi. Međutim, uz to valja odgovoriti na pitanje kako je trajna, to jest neprekidna molitva, ponajprije u smislu recitiranja molitava ili drugih tekstova, postala jednom od bitnih sastavnica i obveza monaškoga života i na koji način se je artikulirala. Monasi su, naime, osjećali svojom dužnošću vjerno ispuniti evanđeosku odredbu o neprekidnoj molitvi. O tome svjedoče gotovo svi značajni autori utemeljitelji, »teoretičari« monaške duhovnosti poput Origena, Evagrija Pontskoga, Kasijana. ${ }^{29}$ Za njima nisu zaostajali niti drugi sveti oci koji su sve vjernike poticali na molitveni život i na iskustvo neprekidne molitve. ${ }^{30}$

Nisu svi jednako shvaćali preporuku o neprekidnoj molitvi. Dok su ju jedni tumačili doslovno, u određenim su je zajednicama i asketskim pokretima olakšavali većim naglaskom na čitanje ili recitiranje svetopisamskih tekstova nego na osobnu molitvu i nadahnuće. Najprikladniji od svih tekstova bili su upravo psalmi, jer su po sebi bili molitve, a i bilo ih je lakše pamtiti i ponavljati. Tako se u monaškim krugovima rane Crkve potreba trajne molitve nije dovodila u pitanje, premda nije u svima jednako shvaćen Pavlov izraz »bez prestanka«. Doslovno shvaćanje Pavlova izraza je kod takozvanih akemeta (ŠPIDLÍK 2007: 194), dok je povezivanje molitve sa svakodnevnim radom u primjeru svetoga Augustina (ŠPIDLÍK 1995: 288-290). ${ }^{31}$ Svakako će u prvim monaškim zajednicama i pokretima ostati otvoreno pitanje omjera između molitve i rada, to jest problem koliko vremena čemu treba posvetiti u danu.

U tom povijesnom hodu sveti Benedikt će staviti točku na spomenute procese, te će pronaći salomonsko rješenje kako za način neprekinute molitve, tako i za omjer između rada i molitve u monaškom životu. Sveti će Benedikt

${ }^{29}$ Više o tome vidi u LEVKO 2000: 4-7. Autor pokazuje da su se u monaškim krugovima, vježbajući neprekinutu molitvu, ostvarivala dva druga cilja: unutarnje jedinstvo s Bogom (riječima ili bez riječi) i otkriće vrijednosto kratkih molitava.

${ }^{30}$ Glede poticaja na molitveni život kod crkvenih otaca vrlo je jasan primjer svetoga Hilarija iz Poitiersa (usp. BODROŽIĆ 2009: 60-62) ili pak onaj svetoga Ambrozija Milanskoga (usp. BONATO 2009: 203-210).

${ }^{31}$ Autor navodi kako su mnogi duhovni pisci prvih vremena (npr. Evagrije, Maksim Ispovjedalac i dr.) bili uvjereni da Sveto pismo ne može zahtijevati nemoguće, te da zato mora biti i rješenje na poziv na molitvu bez prestanka. Monaška zajednica akemeta ('nespavajući') vjerovala je da treba u samostanu biti trajna molitva, te su se onda smjenjivali u trajnoj molitvi skupine monaha. Mesalijanci su pak, u ime molitve, odbijali bilo kakav rad. Odgovor na problem je već iznašao bio Origen koji je govorio o potrebi da se sjedini rad s molitvom i molitva s radom, čime cijeli život postaje molitva. I sveti Augustin će potom preuzeti ovo rješenje, te će ga i otvoreno zastupati u svom djelu De opere monachorum, inzistirajući na važnosti manualnoga rada u monaškom životu. 
uspostaviti ravnotežu između molitve i rada tako da će molitva ipak imati svoju trajnost, to jest odvijat će se u dnevnim i tjednim ciklusima koji nikada ne prestaju. Odredivši da broj dnevnih molitava ne bude pet, već sedam, Benedikt će ostati vjeran svetopisamskome jeziku u kojemu broj sedam predstavlja savršenstvo, to jest trajnost.

Isto tako, uređujući molitveni život monaha u zadanim ciklusima dana i tjedna, sveti Benedikt će razvijati svijest o potrebi neprekinute molitve. Pri tome će pokazati i praktičnu razboritost, za razliku od zajednica (i neke ovdje spomenute) koje su se upravo zbog doslovnoga shvaćanja potrebe za neprestanom molitvom našle u položaju da odredbu o stalnoj molitvi nisu mogle ispuniti. Određujući Pravilom da monasi u tjedan dana izmole cijeli Psaltir, Benedikt će očito pristajati uz stav da u životu monaha treba njegovati svijest o cjelovitosti molitve, jer samo takva molitva može zahvatiti cjelovit život. Ipak, odredivši tjedan (a ne jedan dan) kao vrijeme da se Psaltir izmoli od početka do kraja, uspio je naći održivu mjeru - poruka da monaški život uključuje cjelovitu molitvu u tom je vremenskom razdoblju bila ostvariva.

Molitva je morala biti cjelovita i zbog toga jer je u monaškoj molitvi prisutna želja da se cjelovito slavi jedinstveno Božje stvarateljsko i Kristovo spasenjsko djelo, te se takva potreba izražavala molitvom cijeloga Psaltira. A jer molitva služi i za posvećenje ljudskoga rada, te nadasve vremena, pretvarajući ga u milosno vrijeme spasenja, to jest u vječnost, odvijala se u zadanim ciklusima. U tom smislu monasi već sada molitvom časova vrše službu trajnoga davanja hvale Bogu, koju danju i noću u nebu vrše anđeli, ističu ćokovski monasi u uvodu izdanja Pravila (PB 2008: 40). Oblikujući molitvu monaha na ovakav način Benedikt neće odstupiti od svetopisamskih parametara, jer će njegovo Djelo Božje biti potpuno svetopisamska molitva, kako svojim sadržajem tako i načinom provedbe u svakodnevnom životu. Usidrena u evanđeoskom duhu molitve kao Djela Božjega benediktinska duhovnost će potom težiti jedinstvu molitve i drugih djela s ciljem da se ostvari posvećenje cjelokupnoga života.

\section{ZAKLJUČAK}

Oblikovanje liturgije časova i njezino značenje za Crkvu ne može se svesti samo na svetoga Benedikta i njegove monahe, ali se može reći da su oni za zapadno kršćanstvo predstavljali krajnju točku razvoja molitvenoga života. Nošeni odredbama Pravila uspjeli su usustaviti molitvenu praksu Crkve u 
smislenu organičku cjelinu koja je izrasla iz molitvenoga duha Svetoga pisma, a ostavila je pečat u profiliranju Crkve kao zajednice molitve. Sveti Benedikt ovu molitvu neće smatrati svojom već Božjom, a time i crkvenom, jer je od Crkve primio poticaj za molitvu, kao i sav sadržaj, te je Crkvi samo vratio nazad uređeni molitveni obrazac.

Proces »borbe protiv vremena molitvom« ili proces gospodarenja vremenom, započet $u$ počecima Crkve, pronašao je u benediktinskoj duhovnosti cjelovit i razrađen izričaj. Naime, kršćani, premda se služe istim pojmovima za vrijeme koji su u uporabi u helenističkome svijetu, daju im novo značenje, radikalno drukčije poradi prisutnosti Boga u svijetu i vremenu. Njegovu prisutnost, kao i stvarateljsko i otkupiteljsko djelo Crkva će slaviti u liturgiji, s posebnim naglaskom na liturgiju časova kojoj je bitna zadaća posvećenje vremena. A kako bi se taj cilj ostvario sustavno i cjelovito, već od apostolskih vremena Crkva je prakticirala molitvu kao neprekinutu, zajedničku i biblijsku, što će biti temelj i kasnijih molitvenih obrazaca u kršćanskim zajednicama. Kao kruna procesa započeta naukom i primjerom Isusa Krista, te zdušno prihvaćana od apostola i Crkve utemeljene na njihovu svjedočanstvu, različite monaške zajednice i pokreti trudili su se dosljedno provesti u praksu evanđeoske poticaje na molitvu.

U tom duhu su se i benediktinski monasi, slijedeći božanske upute Svetoga pisma, trudili hvatati ritam drukčiji od štetnoga svjetskog i svjetovnog ritma sa svim njegovim posljedicama. Molitvom oni hvataju ritam Božje vječnosti po kojem postaju gospodari vremena, a susrećući Boga intenzivno u ritmu neprekinute molitve, zadržavaju trajnu mladost duha. Samo snažna duhovnost, vjerna poticajima Duha Svetoga, mogla je pobijediti vrijeme i dati životu novu kvalitetu, bilo s obzirom na kvalitetu unutar 24-satnog ciklusa svakoga pojedinoga dana, bilo s obzirom na cjelokupnu povijest koja je iz dana u dan usmjerena prema vječnom eonu. Ritmizirajući vrijeme vječnošću i život Božjom prisutnošću, monasi zamjenjuju ciklus sudbinskoga vremena s ljubavnim ciklusom zaljubljenika koji nestrpljivo i s čežnjom iščekuje svoga zaručnika. Zato molitveni ciklus u koji se monah daje uvući nije mehaničko kruženje, već je trenutak susreta sa živim trojedinim Bogom Ocem i Sinom i Duhom Svetim koji im ispunjava dane svojim životom, te jamči konačnu pobjedu nad vremenom i ulazak u blaženu vječnost. 


\section{IZVORI}

Časoslov rimskog obreda, I-IV. 1996. Zagreb: Kršćanska sadašnjost.

SC. 2008. Konstitucija o svetoj liturgiji »Sacrosanctum Concilium«, Drugi vatikanski koncil, Dokumenti. VII. izdanje, popravljeno i dopunjeno. Stjepan Kušar (prir.) Zagreb: Kršćanska sadašnjost, 3-60.

Teološki rječnik. 1992. K. Rahner, H. Vorgrimler (ur.). Đakovo: Forum bogoslova.

\section{LITERATURA}

ADAM, A. 1992. Foundations of Liturgy. An Introduction to its History and Practice. Collegeville - Minnesota: Liturgical Press.

ASTI, F. 2007. Introduzione alla vita della preghiera del cristiano lungo i secoli. C. Rossini; P. Sciadini (ed.). Enciclopedia della Preghiera. Vatikan: Libreria Editrice Vaticana, 509-531.

AUGUSTIN, A. 1973. Ispovijesti. S. Hosu (prev.). Zagreb: Kršćanska sadašnjost.

BODROŽIĆ, I. 2009. La preghiera nei Padri latini dei secoli IV e V. Salvatore Panimolle (ed.). Preghiera nei Padri dei secoli IV e V. Dizionario di spiritualità biblico patristica 53. Roma: Borla, 50-137.

BONATO, A. 2009. Sant'Ambrogio: La preghiera nella vita del cristiano. Salvatore Panimolle (ed.). Preghiera nei Padri dei secoli IV e V. Dizionario di spiritualità biblico patristica 53. Roma: Borla, 138-225.

CANOPI, A. M. 2011. Krotkost: lice monaha. Duhovno i zajedničko čitanje Pravila svetoga Benedikta u ključu krotkosti. Slavko Antunović (prev.). Ćokovac: Benediktinska udruga Nard.

CIPRIJAN, Sv. 1987. Jedinstvo Crkve. Euharistija. Molitva Gospodnja. M. Mandac (prev.). Makarska: Služba Božja.

CRNČEVIĆ, A.; I. ŠAŠKO. 2009. Na vrelu liturgije. Zagreb: Hrvatski institut za liturgijski pastoral.

DATTRINO, L. 1984. Il primo monachesimo. Roma: Edizioni Studium.

FRØYSHOV, S. S. 2010. The Formation of a fivefold cursus of Daily prayer in pre-constantinian Christianity: Backward inferences from later periods. D. Galadza; N. Gli-

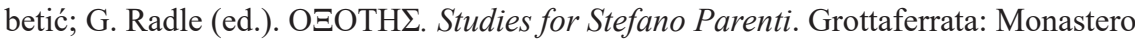
Esarchico.

GRIBOMONT, J. 2008. Salmi (Libro dei). A. di Berardino (ur.). Nuovo Dizionario Patristico e di Antichità Cristiane III. Genova - Milano: Marietti 1820, 4664-4667.

IGNACIJE ANTIOHIJSKI. 2010. Pisma. B. Jozić (prev.), I. Bodrožić (ur.). Split: Verbum.

IOPPOLO, A. M. 2006. Stoicismo, V. Melchiorre (ed.). Enciclopedia Filosofica, vol. XI. Milano: Bompiani, 11105-11109.

LEON-DUFOUR, X. 1980. Rječnik biblijske teologije. J. Turčinović (ur.). Zagreb: Kršćanska sadašnjost, 1461-1465. 
LEVKO, J. 2000. Cassians's Prayer for the 21st Century. Scranton: University of Chicago Press, 4-7.

LORENZIN T. 2001. Introduzione. T. Lorenzin (ed.). I Salmi. Nuova versione, introduzione e commento. Milano: Paoline, 11-37.

MARSILLI, S. 1988. Liturgia. D. Sartore; A. M. Triacca (ed.). Nuovo Dizionario di Liturgia. Milano: San Paolo Edizioni, 678-680.

MONAH DOROTEJ. 2006. Povijest monaštva. Split: Verbum.

OGLIARI, D. 2014. Tempus monasticum. Razmišljanja o arhitekturi vremena u Pravilu svetog Benedikta. V. Kovačić; J. Milanović (ur.). Benediktinski samostan sv. Nikole u Trogiru. Duhovnost i kultura u okrilju Virgines Dei. Trogir: Benediktinski samostan sv. Nikole, 11-24.

PB. 2008. Pravilo sv. Benedikta. Ćokovski monasi (ur.). Ćokovac: Nard.

PEHAR, M. 2014. Liturgija časova i kairološko razumijevanje vremena. V. Kovačić; J. Milanović (ur.). Benediktinski samostan sv. Nikole u Trogiru. Duhovnost i kultura u okrilju Virgines Dei. Trogir: Benediktinski samostan sv. Nikole, 49-63.

PEHAR, M. 2020. Psalamsko Trojstvo - nastanak i ikonografsko-teološki razvoj od psaltirske ilustracije do trinitarnog ikonografskog tipa. Slovo 70: 1-22.

PENCO, G. 1983. Storia del monachesimo in Italia. Milano: Jaca Book.

PENCO, G. 1993. Monachesimo e cultura. Seregno: Abbazia San Benedetto.

PITTA, A. 2007. La preghiera nelle lettere di Paolo e nelle prime comunità cristiane. C. Rossini; P. Sciadini (ed.). Enciclopedia della Preghiera. Città del Vaticano: Libreria Editrice Vaticana, 142-158.

PRINZIVALLI, E. 2000. Salmi (scritti esegetici sui). A. Monaci Castagno (ed.). Origene. Dizionario la cultura, il pensiero, le opere. Roma: Città Nuova Editrice, 422-424.

PSEUDO-IPPOLITO. 1996. Tradizione apostolica. E. Peretto (tal. prev.). Roma: Città Nuova Editrice.

RAVASI, G. 1988. Salmi. P. Rossano; G. Ravasi; A. Girlanda (ed.). Nuovo Dizionario di Teologia Biblica. Milano: Edizioni San Paolo, 1399-1412.

REALE, G. 1997. Storia della Filosofia antica, vol. V. Milano: Vita e Pensiero.

RORDORF, W. 2006. Didachè. A. di Berardino (ed.). Nuovo Dizionario Patristico e di Antichità Cristiane. Milano - Genova: Marietti 1820, 1400-1402.

SIPIORA, P. 2002. Rhetoric and Kairos. Albany (NY): State University of New York Press.

ŠPIDLÍK, T. 1995. Spiritualità dell'Oriente cristiano. Cinisello Balsamo: San Paolo Edizioni.

ŠPIDLÍK, T. 2007. Il monachesimo secondo la tradizione dell'Oriente cristiano. Roma: Lipa.

TENŠEK, T. Z. 2003. Asketsko-monaška duhovnost otačkog razdoblja. Zagreb: Kršćanska sadašnjost.

TERTULLIANUS. 1954. De oratione. E. Dekkers (ed.). Corpus Christianorum. Series Latina I. Turnhout: Brepols.

Upute apostolske. 2010. B. Jozić (prev.). Split: Verbum. 
Sum mary

\section{Ivan BODROŽIĆ}

\section{PROCESS OF THE FORMATION OF THE LITURGY OF THE HOURS AND CHRISTIAN UNDERSTANDING OF TIME IN CONTEXT OF BENEDICTINE SPIRITUALITY AND RULES}

In this article the author discusses the origin and formation process of the liturgy of the hours as the official prayer of the Church, which was designed as a prayer by which time is consecrated. After having defined the terminological framework of the terms liturgy of hours and time, the author begins his research by returning to the period of apostolic communion in which, reading the New Testament texts, he will conclude that prayer should contain three essential features: be continuous, common and biblical. In the post-apostolic period, following this thread, it will be shown that the psalm prayers were imposed in Christian communities as a privileged Christian prayer (of course along with the Lord's Prayer) that met those criteria. Thus it is evident that Christians already in the $2^{\text {nd }}$ and $3^{\text {rd }}$ centuries developed prayer in five prayer moments during the day: Morning and Vespers were central prayers, and to them were added the prayers of the Third, Sixth and Ninth Hour. To all appearances, certain psalms were prayed at the appointed time, but today it is not possible to conclude exactly which ones.

From this paper it becomes clear that the monastic movement gives its stamp to the whole process, where the most important role for Western Christianity will be played by St. Benedict, who will play a special role with his Rule. Responding to the challenges of the time, he will give the monk's prayer a cyclical form, and will increase the rhythm of five prayer moments in the day to seven, i.e. eight if the night Vigil is included. Starting from the fact that the number seven signifies perfection, the rhythm of the seven daily prayer moments will symbolically signify prayer as a continuous activity. Having regard to the weekly praying cycle, Benedict will order all 150 psalms of the Psalter to be prayed within it, thus ensuring the integrity of the prayer. According to his Rule, the prayer of the psalms, or the Work of God as he calls it, not only beat a rhythm to the monk's all day and week, but grafted him onto the history of salvation by turning his time into a blessed eternity. As a means of consecrating time that has its uninterrupted course in daily and weekly cycles, the prayer of the hours fully met the evangelical criteria set by Jesus and the apostolic community, and it is understandable why it is still accepted in the Church as the official prayer of the Church.

Key words: Liturgy of the Hours, time, Benedict's Rule, Benedictine spirituality, prayer, Psalter

Ivan BODROŽIĆ

Catholic Theology Faculty

Split (Croatia)

ivan.bodrozic@gmail.com 
